\title{
Patients' and caregivers' views on spiritual care and their understanding of spiritual needs in persons with dementia: a meta-synthesis
}

Dementia: the international journal of social research and practice (DEM-15-0136).

Liv Skomakerstuen Ødbehr, ${ }^{1,2,}$ Solveig Hauge, ${ }^{3,4}$ Lars Johan Danbolt ${ }^{5,6}$ Kari Kvigne, ${ }^{1,7}$

${ }^{1}$ Department of Nursing, Faculty of Public Health, Hedmark University College, PO Box 400, N-2418 Elverum, Norway

${ }^{2}$ Institute of Health and Society, Department of Nursing Science, University of Oslo, PO Box 1130, Blindern, 0318 Oslo, Norway

${ }^{3}$ Institute of Health Sciences, Faculty of Health and Social Studies, Telemark University

College, 3901 Porsgrunn, Norway

${ }^{4}$ Centre of Caring Research - Southern Norway, Institute of Health Sciences, Faculty of

Health and Social Studies, Telemark University College, 3901 Porsgrunn, Norway

${ }^{5}$ Centre for Psychology and Religion, Innlandet Hospital Trust, PO Box 68, 2312 Ottestad, Norway

${ }^{6}$ Oslo School of Theology, PO Box 1153, Blindern, 0318 Oslo, Norway

${ }^{7}$ Nesna, University College, Institute of Nurse Education, 8700 Nesna, Norway

Corresponding author: Liv Skomakerstuen Ødbehr

Department of Nursing, Faculty of Public Health, Hedmark University College, PO Box 400, N-2418 Elverum, Norway

Phone: +47 62430269 (work), +4795907984 (mobile)

Fax: +4762430001

Email: liv.odbehr@hihm.no; 


\begin{abstract}
Aims of the study: To synthesize research that investigated how patients and caregivers view spiritual care, come to understand the spiritual needs of people with dementia, and how caregivers provide care congruent with peoples' needs. There is limited knowledge about the characteristics of spiritual care for people with dementia in research.
\end{abstract}

Methods and study design: We conducted a meta-synthesis using Noblit \& Hare's metaethnography. A synthesis of eight qualitative, empirical, primary studies that explored spiritual care in the context of dementia care was performed.

Findings: The first-level synthesis revealed that spiritual care for persons with dementia was described in the forms of i) performing religious rituals with patients that provide a sense of comfort and ii) coming to know the person, which provides opportunities to understand a person's meaning and purpose. iii) Attending to basic needs provides an opportunity to appreciate others' vulnerability and humanness.

Conclusions: This meta-synthesis reveals that spiritual care intended to help persons with dementia to express their faith and religious beliefs, and help patients experience connectedness to self, God/deity and other persons. Spiritual care can occur in addressing patients' vulnerability by confirming them as valuable people and helping them experience meaning in life.

Key words: Dementia, spiritual care, spirituality, holistic care, meta-synthesis 


\section{Introduction, defining the topic}

Although several research studies have been conducted to explore and describe spiritual care for different groups of people (Clarke, 2009; Pesut, 2008; Ross, 2006), there is limited knowledge regarding the characteristics of spiritual care for people with dementia (Carr, Hicks-Moore, \& Montgomery, 2011). Dementia is one of the major causes of disability and dependency among older people worldwide. In 2010, as many as 35.6 million people were reported to be living with dementia worldwide, both in high- and low-income countries, and there are 7.7 million new cases each year. The total number of people with dementia is expected to double by 2030 (65.7 million) and to triple by 2050 to 115.4 million (WHO, 2012). Dementia affects the brain and is chronic and progressive in nature. The disease is characterized by impaired memory, thinking, comprehension, communication abilities and orientation due to organic brain changes (Engedal \& Haugen, 2004; WHO, 2012). In the final phase of the disease, patients are entirely dependent on others for care and cannot attend to their own personal care (Engedal \& Haugen, 2004). The cognitive decline places a demand on nurses to implement spiritual care as part of holistic care for their patients (Baldacchino, 2011; Borneman, Ferrell, \& Puchalski, 2010; Kim, Reed, Hayward, Kang, \& Koenig, 2011).

In performing this meta-synthesis, we have considered the concept of spirituality as an umbrella term by assuming that religiosity is a form of spirituality that is expressed in the forms of doctrines, attributes such as rituals, and the use of symbols and humans expressions of faith and belief systems (Farran, Paun, \& Elliott, 2003; Group, 2006; Koenig, 2008).

Descriptions of spirituality refer to humans' needs to experience meaning, purpose (Agrimson \& Taft, 2009; Delgado, 2005; Smith, Hall, Gerdner, \& Buckwalter, 2006), connectedness (O'Brien, 2011; Tanyi, 2002), and a transcendent dimension in life (Pargament, 2007; Teixeira, 2008). Transcendence is described in research as something exceedingly out of the ordinary in a particular experience (Haugan, Rannestad, Garasen, Hammervold, \& Espnes, 
2012; Haugan, Rannestad, Hanssen, \& Espnes, 2012; Pargament, 2007; Schnell, 2011).

Spiritual care is generally based on meeting humans' expressions of spirituality and spiritual needs (Narayanasamy, 2004). People with dementia do not always express their spiritual needs clearly due to their cognitive decline, which makes caring for the spiritual dimensions in their lives challenging (Sullivan \& Beard, 2014). Spiritual care is described as nurses' abilities to listen to people and to guide them in difficult questions concerning life and death (Creel \& Tillman, 2008; Gaskamp, Sutter, Meraviglia, Adams, \& Titler, 2006). Spiritual care means caring for important values in peoples' lives in terms of inner peace and hope (Newlin, Knafl, \& Melkus, 2002). Other descriptions emphasize that spiritual care includes working intuitively and altruistically to meet a person's spiritual needs (Sawatzky \& Pesut, 2005). Lunn (2003) states that spiritual care is: "Meeting people where they are and assisting them in connecting or re-connecting to things, practices, ideas and principles that are their core of their being - the breath of their lives, making connection between yourselves and that person" (p. 154). Lunn's (2003) emphasis on connections is interesting in the context of people with dementia because reduced short-term memory creates a split in the patients' experiences of past and present, and the definition emphasises a key role for caregivers in assisting these patients.

\section{Clarifying the aim}

Few meta-syntheses have been published within the field of spiritual care (Hodge \& Horvath, 2011; Hodge, Horvath, Larkin, \& Curl, 2012; Rykkje, Eriksson, \& Råholm, 2011), and none have discussed dementia care, which in turn can lead to uncertainty in practice for nurses (Sessanna, Finnell, \& Jezewski, 2007). An important question is how health care professionals can meet the spiritual needs of people with dementia, as the research mainly provides knowledge about spiritual care for cognitively healthy people. Thus, there is a need 
to expand the knowledge of spiritual care to people with dementia. The aim of the study was to synthesize research that investigated how patients and caregivers view spiritual care, come to understand the spiritual needs of people with dementia, and how caregivers provide care congruent with peoples' needs.

The term caregiver is used here to describe professional groups, including nurses (registered nurses, RNs), nursing assistants, licensed practical nurses (LPNs), therapists, physicians, priests and chaplains, as presented in Table 3. The term "patient" is used throughout the article to describe people with dementia receiving care at home and in institutions.

\section{Methods and study design}

The meta-synthesis is inspired by Noblit and Hare's (1988) methods of metaethnography. The synthesis of qualitative research involves compiling findings from several studies on a chosen theme. The purpose of this is to go beyond the descriptions of primary studies; thus, the synthesis is based on published findings rather than primary data and therefor has the ability to provide a more complete understanding of phenomena.

This meta-synthesis is interpretative, the research question is iterative (Saini \& Shlonsky, 2012), and the research design includes various types of qualitative studies, e.g., phenomenological, grounded theory and ethnographic (Gough, Thomas, \& Oliver, 2012; Saini, 2012). Noblit and Hare (1988) suggest seven phases for syntheses, with the phases overlapping to some extent. This article's structure is based on the phases that are described in Table 1. 
Insert Table 1. Noblit and Hare's (1988) phases of conducting a meta-synthesis

about here.

\section{Deciding what is relevant to the initial interest (Phase 2)}

\section{Search strategy}

In accordance with phase 1 (Noblit \& Hare, 1988), we defined the aim of the study. We conducted a literature search in March 2014 (phase 2). Initially, we wanted to study spiritual care from the perspectives of nurses who worked in nursing homes, but few studies were available. We expanded our search and included studies with the perspectives of caregivers and patients. The databases used were Medline, Ovid Nursing, PsycINFO, and CINAHL. The relevant MeSH-terms in Medline, Ovid Nursing, and PsycINFO were as follows: spiritual care, nursing care, nurse's practice, holistic nursing, pastoral care, dementia, dementia nursing, spirituality, spiritual, spiritual needs, religion and religious. The search terms in CINAHL were spiritual care in medicine, dementia and nursing home. We used the terms and searched using different combinations of them. The procedure for the selection of articles was based on the flow diagram from the PRISMA Group (Liberati et al., 2009; Moher, Liberati, Tetzlaff, \& Altman, 2009) and is described in the following section.

\section{Insert Table 2. Article search flowchart, about here}

The literature search led to the discovery of 395 articles. We also searched key journals (e.g., Dementia and the Journal of Religion, Spirituality \& Aging). The following free text keywords were used: religiousness OR beliefs OR pastoral care AND spiritual care AND dementia care. The search resulted in the inclusion of 11 additional relevant articles. 


\section{Inclusion and exclusion criteria.}

A new assessment of the remaining articles $(n=406)$ was conducted by the first author (XXX). Further selection of the articles was conducted on the basis of the abstracts, headings, and subject matter in accordance with the inclusion criteria, as well as an assessment of the thematic relevance. The general inclusion criteria were that studies had to be empirical, qualitative, peer-reviewed primary studies that were published between January 2004 and March 2014. They were also required to be written in English, available with abstracts and based on the perspectives of caregivers and patients. Studies with outcomes such as quality of life, acute care, dialysis, loneliness, stroke, pain, restraints, and depression $(n=289)$ were excluded. All articles with a theoretical or quantitative design were excluded, as were book reviews and dissertations $(n=44)$. Studies in languages other than English $(n=26)$ were also excluded, as were any duplicates (9).

A new assessment of the remaining articles $(n=38)$ was conducted by the first $(\mathrm{xxx})$ and last authors (xx). The emphasis was placed on empirical studies with qualitative designs, including phenomenological-hermeneutical, ethnographic, grounded theory and case study designs. Furthermore, 23 studies were excluded because they were not specifically about spiritual needs and spiritual care in dementia nursing. One of the studies was unobtainable and was therefore excluded. Fourteen studies were then assessed for eligibility. We further excluded 4 studies due to divergent subject matter or/and irrelevance.

\section{Quality appraisal}

Two of the authors (the first and last authors) used the checklist by Malterud (2001) to guide the quality appraisal of the remaining articles $(n=10)$. The checklist ensured a thorough review of each article's purpose, reflexivity, method, design, sample, theoretical framework, 
methodology, analysis, findings, discussion and conclusion. All of the selected studies had acceptable methodological qualities, except for two studies that were excluded based on the checklist. Eight studies were finally included in the qualitative synthesis (Beuscher \& Grando, 2009; Bursell \& Mayers, 2010; Carr et al., 2011; Dalby, Sperlinger, \& Boddington, 2012; Gijsberts, van der Steen, Muller, Hertogh, \& Deliens, 2013; MacKinlay \& Trevitt, 2010; Sullivan \& Beard, 2014; Welsh, Moore, \& Getzlaf, 2012).

\section{Characteristics of the studies included}

The studies included were primary studies conducted between 2009 and 2014. Three of the studies were from the United States (US), one was from Australia, one was from the United Kingdom (UK), one was from the Netherlands, and two were from Canada (one of which was from Newfoundland). These are also outlined in Table 3. The studies were conducted in dementia care services/units, long-term care facilities, nursing homes, home care settings, and hospitals. The methods used included interviews, observations and reminiscence groups. During the literature search, we found that none of the primary studies we selected had a unilateral nursing perspective. Although we searched specifically for studies containing that perspective, none were available. The studies that we finally included in the metasynthesis had a mix of informants. In four of the studies, the participants were residents/patients ( $\mathrm{n}=147)$, (Beuscher \& Grando, 2009; Dalby et al., 2012; MacKinlay \& Trevitt, 2010; Welsh et al., 2012). In the other four studies, there was a mix of participants, such as health care professionals $(n=30)$ and patients/residents $(n=39)$ and their family members (n=49) (Bursell \& Mayers, 2010; Carr et al., 2011; Gijsberts et al., 2013; Sullivan \& Beard, 2014).

Insert Table 3 about here. Presentation of the studies included 


\section{Methodological considerations}

Trustworthiness in qualitative research parallels the standards for validity and reliability in quantitative research (Denzin \& Lincoln, 2011; Streubert \& Carpenter, 2011). The assessments of trustworthiness in meta-synthesis are based on the researchers comprehensive description in the synthesis which reflects the findings in the included studies (Sandelowski, 2008). The findings in this meta-synthesis are based on primary qualitative empirical studies that were conducted in certain contexts. Sandelowski $(2006 ; 2008)$ refers to several challenges regarding the integration of qualitative research. These challenges include the studies' different philosophical assumptions, epistemologies and ontologies, and because the findings are context bound, it might be difficult to synthesize them (Sandelowski, 2006; 2008). We chose to be transparent and open with the analysis process by explaining the steps in detail as a way to strengthen both the trustworthiness and credibility of the synthesis.

Though the transferability from one context to another implies limitations, the findings may easily be recognized in different contexts of dementia care. The dependability rests on the methodological differences and the changes in methodological variations over time. We have chosen studies from a short time period (2009-2014) not only to avoid effects from discrepancies and changes in the studies' methodological qualities but also to obtain the latest knowledge available because the knowledge base within this field expands quickly. Confirmability was maintained by using Noblit \& Hare's (1988) design for metaethnographical syntheses. We systematically worked through the phases in the synthesis and documented the different stages during the process. Authenticity is demonstrated by showing the fairness and strength of the interpretation and the impact on the participants using citations in the presentation of the first level of the synthesis (Campbell et al., 2011; Streubert \& Carpenter, 2011). 


\begin{abstract}
Analysis
First-level analysis: Reading the studies (phase 3)

We considered the results sections of the primary studies as the outcome of a firstlevel analysis (Dahl, Fylkesnes, Sorlie, \& Malterud, 2013). We formulated the following question as a starting point for the analysis when reading the articles that were included: 'Which analytical concepts (metaphors) and themes are used to describe spiritual needs and spiritual care in dementia care'? All articles $(\mathrm{n}=8)$ were read in light of such question.
\end{abstract}

\title{
Second-level analysis: Determining the relationships between the studies
}

\section{(phase 4)}

The second-level analysis that is described below constituted the first-level synthesis of the eight articles in the sample (Dahl et al., 2013), which, in our study, was made by two of the authors $(\mathrm{xxx}, \mathrm{xx})$. The first-level synthesis builds an interpretation from the original empirical studies by i) identifying interpretations of the participants and the original researchers and ii) developing a new understanding that goes beyond the individual primary studies (Campbell et al., 2011). We read the findings and discussions in the articles closely. All of the articles were processed based on the article by Carr et al., 2011, which was used as an index paper, and each subsequent paper that was brought into the synthesis was compared with it. We made a grid in which the references to each study were listed horizontally, and the interpretive metaphors, concepts and themes outlined by the primary authors were listed vertically. The metaphors/concepts and/or themes in each article -were compared with the metaphors, concepts and/or themes and their interactions in the other articles (Gough et al., 2012; Tranvåg et al., 2013). This allowed us to understand how the empirical studies were 
related (reciprocal) (phase 4) and how (and if) they differed from each other (reputational) (Noblit \& Hare, 1988; Whittemore, \& Knafl, 2005). The outcome of the second-level analysis is presented as three themes that can be viewed in Table 4 .

Insert Table 4. First-level synthesis based on the second-level analysis, about here.

\section{Findings}

\section{First-level synthesis: 'Translating' the studies in to each other (phase 5)}

Throughout the synthesis, we sought to be faithful to the original authors' meanings in the primary studies and to find the whole among a set of parts (line of arguments) (phase 5). The first-level synthesis is described by three main headings: i) performing religious rituals with patients provides a sense of comfort, ii) coming to know the person provides an opportunity to understand the person's meaning and purpose, and iii) attending to basic needs provides an opportunity to appreciate another person's vulnerability and humanness.

\section{Performing religious rituals with patients provides a sense of comfort}

The first-level synthesis revealed that the caregivers described spiritual care as a way to enable the patients to participate in religious practices. Religious practices were described as reading the bible, attending church, or meditating, which the caregivers believed helped the patients stay mentally intact (Bursell \& Mayers, 2010; Carr et al., 2011; Sullivan \& Beard, 2014). Attending church services contributed to maintaining continuity and the experience of God's involvement in patients' lives (Carr et al., 2011; Dalby et al., 2012; Sullivan \& Beard, 2014). Several studies highlighted that facilitating the patients' prayers was seen as a way to 
help the person with dementia to express their faith (Dalby et al., 2012; Sullivan \& Beard, 2014). Patients claimed that continuity in their faith and religious practices was a source of strength that gave them optimism and an experience of having a greater purpose in life (MacKinlay \& Trevitt, 2010).

Religious and spiritual frameworks provided benefits in the forms of resilience, peace and serenity for the patients (Bursell \& Mayers, 2010; Carr et al., 2011). The patients said that trust in God helped them cope with the vulnerability of not being able to remember (Beuscher \& Grando, 2009; MacKinlay \& Trevitt, 2010; Sullivan \& Beard, 2014). Welsh et al. (2012) referred to the following residents narrative:

"So I come in, I take my prayer book out a couple of times a day. I read a chapter in the bible. I am a firm believer of that stuff... I think there is something after death and I think that even if you have something wrong with you, there is always something greater... I think something comes over you for a purpose... All I do is sit here and look out the window at the lights and how beautiful it is. And God has given me another day". (p. 189)

The experiences of talking to God, viewing God as a friend and maintaining continuity in the relationship with God, Jesus, a divine force or another deity were emphasized in several of the included studies (Beuscher \& Grando, 2009; Dalby et al., 2012; Sullivan \& Beard, 2014; Welsh et al., 2012). Religious identities were reported to provide hope, a sense of comfort and support in the lives of people with dementia, which are central to their feelings of safety (Dalby et al., 2012; Gijsberts et al., 2013). 


\section{Coming to know a person provides an opportunity to understand their meaning and purpose}

The first-level synthesis revealed that the caregivers emphasized the importance of promoting the patients' values in life. Important values mentioned were love, openness, gratitude, being understood and comforted, forgiving and gaining wisdom (Dalby et al., 2012). A requirement was that caregivers knew the patients' life stories and background so that they could affirm them and meet their needs (Carr et al., 2011).

Spiritual care was intended to prevent the patients from feeling lonely and isolated. Caregivers achieved this through listening to the patients, spending time with them, and trying to preserve the persons' personality and integrity (Bursell \& Mayers, 2010; Carr et al., 2011; Welsh et al., 2012). It was seen as a way to strengthen the patients' senses of personhood, which contributed to feelings of hope for the future (Dalby et al., 2012). Secure relationships lead to patients feeling connections in the moment with themselves and other people (Beuscher \& Grando, 2009; MacKinlay \& Trevitt, 2010). The patients reported that such relationships promoted well-being and the lessening of spiritual pain and emotional struggling (MacKinlay \& Trevitt, 2010).

The use of music to help patients on spiritual journeys was assessed. Patients said that they felt that music could help them release emotions that they otherwise would not express (MacKinlay \& Trevitt, 2010). The patients highlighted that music and singing hymns was a way to create a supportive and encouraging atmosphere that opened up memories in their lives (MacKinlay \& Trevitt, 2010). 


\section{Attending to basic needs provides an opportunity to appreciate another person's vulnerability and humanness.}

Through the first-level synthesis, we found that caregivers emphasized that engaging in familiar activities gave patients a sense of contribution and a way to support their needs for trust and safety (MacKinlay \& Trevitt, 2010). Several of the studies pointed to the importance of "doing little things" to help the patients cope with activities and experience good moments (Bursell \& Mayers, 2010; Carr et al., 2011). The activities described included painting the patients' nails, having a cup of tea, setting their hair, playing piano, smelling flowers, going for a walk, looking at the sunshine, and baking cakes. Other activities that could be spiritual included reminiscing while looking through photographs and telling stories that encouraged participation (Bursell \& Mayers, 2010) or that were about experiences of spiritual coping (Beuscher \& Grando, 2009). Attending to basic needs may be interpreted as the caregivers embracing the patients' vulnerability and humanness. One concern raised by the caregivers was that the care was characterized as being informal. The caregivers reported that they felt uncertain about and lacked confidence in caring for the patients' spiritual needs (Gijsberts et al., 2013; Sullivan \& Beard, 2014). They felt that this uncertainty was a barrier and a hindrance to fully providing support for this part of the residents' lives (Bursell \& Mayers, 2010).

\section{Second-level synthesis: Synthesize translations (phase 6)}

The small number and coherence of the papers in this synthesis permitted the reciprocal translation of findings for all of the papers to be tabulated. These reciprocal translations were then subject to a process of re-ordering and re-analysis (phase 6) (Campbell et al, 2011; Noblit \& Hare, 1988). The second-level synthesis is based on the results of the 
first-level synthesis. At the end of the synthesis, we refer to an overall interpretation in line with the last point in Noblit \& Hare's (1988) steps for conducting a meta-synthesis: 'Expressing the synthesis' (Phase 7)

The first-level synthesis revealed that people with dementia needed to exercise their faiths (Beuscher \& Grando, 2009; Carr et al., 2011; Dalby et al., 2012; Sullivan \& Beard, 2014; Welsh et al., 2012). Several studies in the current meta-synthesis argued for the importance of expressing faith, but few of the studies gave suggestions for how caregivers could accommodate the patients' expressions of religious faith in practice. MacKinlay and Trevitt's (2010) study showed that spiritual reminiscence was an appropriate way to maintain this side of the patients' religious lives. One question, however, is whether the desire to seek God is as strong for people with dementia as it is for cognitively healthy people.

The first-level synthesis revealed that people with dementia appreciated peace and maintaining contact with God/their deity (Dalby et al., 2012). It is interesting to note that research emphasizes the need for contact with God in the lives of people with dementia (Sullivan \& Beard, 2014), but a large challenge is that many patients fail to take the initiative to maintain their relationship with God in the same way they did previously. Because the patients tend to forget how and why they seek God, it becomes the caregivers task to help the patients remember God again (MacKinlay, 2009). The first-level synthesis revealed that none of the studies that were included in the sample addressed nurses' reflections on if/how patients responded to their own behaviour when the patients' life principles were not followed. Dementia can cause people to be uncritical in their behaviour and to deviate from the values that had been important in their lives (Rokstad et al., 2013). In research with cognitively healthy people, spiritual care is about helping people live in unity with important life values (Narayanasamy, 2004; Ross, 2006). 
Furthermore, the first-level synthesis in the current study revealed that many patients are dependent on relationships with other people to feel valued (Bursell \& Mayers, 2010; Welsh et al., 2012). Many people with dementia gradually lose the experience of themselves during the development of the disease and need assistance to experience a connectedness to self (Cooney, 2014). A new study by Rykkje et al. (2011) found that 'love in connectedness' was a core finding in descriptions of spirituality and that connectedness is about close relationships in which the expressions of love contribute to confirming "the self". Several studies have emphasized humans' relationships with themselves and others when addressing spiritual needs and spiritual care (MacKinlay, 2009; Welsh et al., 2012), as this metasynthesis has also done. The current synthesis found that caregivers explained spiritual care in terms of helping patients to maintain connections to themselves and other people. A study by Haugan et al. (2012) found that self-transcendence improved connections in relationships that were horizontally oriented and had an impact on the experience of well-being. The need for connections with oneself and others is challenging for people with dementia because the disease often leads to isolation and social withdrawal (Cooney, 2014; Rokstad et al., 2013). Nevertheless, connections unfold in a relational context (Reed, 2014), and spiritual care in the form of strengthening the patients' connections to themselves and others seems to be a comprehensive description of spiritual care in dementia.

The first-level synthesis indicated that activities provided a sense of contribution and participation in the lives of people with dementia (Carr et al., 2011; Dalby et al., 2012; Welsh et al., 2012). Cognitive declines often cause people with dementia to forget what had previously given them meaning in their lives (MacKinlay \& Trevitt, 2010). The studies included in this meta-synthesis demonstrated that patients' contributions in relevant activities, 
such as the use of music in different care situations, and participating in small activities, such as drinking tea, styling hair (Carr et al., 2011), smelling flowers or going for a walk (Bursell \& Mayers, 2010), led to experiences of meaning. Descriptions of spiritual care that enhanced the patients' experiences of contribution and participation were linked to the patients' searches for meaning in life. Research has indicated that people inherently seek meaning (Pargament, 1997; Pargament, Magyar-Russell, \& Murray-Swank, 2005) and use various sources in their lives to create and experience meaning (Park, 2010). The sources of meaning develop through a life cycle based on conscious and individual choices. Van de Geer \& Leget (2012) refer to the experience of meaning in the definition of the concept of spirituality. Despite their cognitive impairments, the need for meaning in the lives of patients with dementia seems to be strong in the same way that it is for cognitively healthy people. Nevertheless, only a few of the included studies emphasized the importance of delving into the life stories of the patients to identify their spiritual and/or religious commitments and religious involvement in life (Carr et al., 2011). This could provide essential information about patients' sources of meaningful experiences and could be a way to approach the core areas of the patients' lives (MacKinlay \& Trevitt, 2010). The first-level synthesis revealed that the search for meaning was important to people with dementia. Humans' searches for meaning are well documented in research addressing spiritual needs in both cognitively healthy people (Park, 2010) and people with dementia (Dwyer, Nordenfelt, \& Ternestedt, 2008). The second-level synthesis is presented in Table 5.

Insert Table 5. Second level analysis of spiritual care in dementia care, about here. 


\section{Conclusions: Expressing the synthesis (phase 7)}

This meta-synthesis has revealed that there are three core areas that describe caregivers and patients' perspectives of spiritual care. Spiritual care includes helping people with dementia to express their faith and assist them in their need for a relationship with a God/deity. Furthermore, spiritual care means helping patients re-establish a connection with themselves and their senses of being in turn by supporting and confirming the patients as valued people. The third point is to meet the patients' needs for meaning in life through recognizable and relevant activities, including those that might seem insignificant. The main understanding of spiritual care in dementia care seems to be care for religiosity and faith, connectedness and meaning in life. This study shows that it is still relevant even as dementia progresses.

\section{Limitations}

The inclusion criteria may have resulted in some relevant articles being excluded from the study or not being captured in the literature search, such as articles on the topic of care at the end of life. We also excluded dissertations, book chapters and grey literature, which might have enriched the synthesis. These restrictions may have resulted in data that are not as extensive as they could have been. Nevertheless, the findings are recognized in other research and are considered to be the core parts of spiritual care. A weakness of the study is the marginalized research published within this particular field. 


\section{Implications for research and practice}

The findings in the current meta-synthesis describing spiritual care for people with dementia are much in line with those described for cognitively healthy people, which can be interpreted in two ways. The first perspective is that spirituality is unchangeable in humans' lives, even in cases of severe illness and disease. The other perspective could be that the research failed to reveal the specific experiences of spirituality and spiritual needs in the lives of people with dementia.

Both patients and caregivers in the current synthesis understood spiritual care primarily as religious care. There were few descriptions of different views on spirituality in the studies included in the meta-synthesis. For this reason, there were limited descriptions of different approaches to spiritual care in practice. A broader discussion of the nature of spirituality and religiosity is necessary to develop spiritual care for this group of patients. Here, more research is needed.

None of the primary studies we included in the synthesis had a nursing-specific perspective. Several of the primary studies included different types of health professionals in their selections of participants. Research focusing on nursing practices exclusively in relation to spiritual care for people with dementia in nursing homes is almost non-existent. This side of care needs to be explored further. Many nurses and other caregivers feel that spiritual care is time-consuming, and as a result, it is downgraded in the patients' lives. This meta-synthesis notes that patients experience spiritual care as important and that it gives content and meaning in life. For that reason, it is necessary to develop nursing practices related to spiritual care in dementia care. 


\section{References}

Agrimson, L. B., \& Taft, L. B. (2009). Spiritual crisis: a concept analysis. Journal of Advanced Nursing, 65(2), 454-461. doi: 10.1111/j.1365-2648.2008.04869.x

Baldacchino, D. R. (2011). Teaching on spiritual care: The perceived impact on qualified nurses. Nurse Education in Practice, 11(1), 47-53.

doi: http://dx.doi.org/10.1016/j.nepr.2010.06.008

Beuscher, L., \& Grando, V. T. (2009). Using spirituality to cope with early-stage Alzheimer's disease. Western Journal of Nursing Research, 31(5), 583-598. http://dx.doi.org/10.1177/0193945909332776

Borneman, T., Ferrell, B., \& Puchalski, C. M. (2010). Evaluation of the FICA Tool for Spiritual Assessment. Journal of Pain and Symptom Management, 40(2), 163-173. doi: http://dx.doi.org/10.1016/j.jpainsymman.2009.12.019

Bursell, J., \& Mayers, C. A. (2010). Spirituality within dementia care: perceptions of health professionals. British Journal of Occupational Therapy, 73(4), 144-151. doi: 10.4276/030802210X12706313443866

Campbell, R., Pound, P., Morgan, M., Daker-White, G., Britten, N., Pill, R., \& Donovan, J. (2011). Evaluating meta-ethnography: systematic analysis and synthesis of qualitative research. Health Technology Assessment (Winchester, England), 15(43), 1-164.

Carr, T. J., Hicks-Moore, S., \& Montgomery, P. (2011). What's so big about the 'little things': A phenomenological inquiry into the meaning of spiritual care in dementia. Dementia, 10(3), 399-414. doi: 10.1177/1471301211408122

Clarke, J. (2009). A critical view of how nursing has defined spirituality. Journal of Clinical Nursing, 18(12), 1666-1673. doi: 10.1111/j.1365-2702.2008.02707.x

Cooney, A., Dowling, M., Gannon, , E.,\& Dempsey, L. Murphy, K. (2014). Exploration of the meaning of connectedness for older people in long-term care in context of their 
quality of life: a review and commentary. International Journal of Older People Nursing, 9(3), 192-199.

Creel, E., \& Tillman, K. (2008). The meaning of spirituality among nonreligious persons with chronic illness. Holistic Nursing Practice, 22(6), 303-311.

Dahl, B., Fylkesnes, A. M., Sorlie, V., \& Malterud, K. (2013). Lesbian women's experiences with healthcare providers in the birthing context: a meta-ethnography. Midwifery, 29(6), 674-681. http://dx.doi.org/10.1016/j.midw.2012.06.008

Dalby, P., Sperlinger, D. J., \& Boddington, S. (2012). The lived experience of spirituality and dementia in older people living with mild to moderate dementia. Dementia: The International Journal of Social Research and Practice, 11(1), 75-94. http://dx.doi.org/10.1177/1471301211416608

Delgado, C. (2005). A discussion of the concept of spirituality. Nursing Science Quarterly, 18(2), 157-162. doi: 10.1177/0894318405274828

Dwyer, L. L., Nordenfelt, L., \& Ternestedt, B. M. (2008). Three nursing home residents speak about meaning at the end of life. Nursing Ethics, 15(1), 97-109. http://dx.doi.org/10.1177/0969733007083938

Denzin, N. K., \& Lincoln, Y. S. (2011). The SAGE handbook of qualitative research (4th ed. ed.). Los Angeles: Sage.

Engedal, K., \& Haugen, P. K. (2004). Demens: fakta og utfordringer: en loerebok(3rd. ed.). Sem: Nasjonalt kompetansesenter for aldersdemens. pp 413.

Farran, C. J., Paun, O., \& Elliott, M. H. (2003). Spirituality in multicultural caregivers of persons with dementia. Dementia: The International Journal of Social Research and

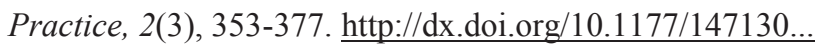


Gaskamp, C., Sutter, R., Meraviglia, M., Adams, S., \& Titler, M. G. (2006). Evidence-based guideline: Promoting spirituality in the older adult. Journal of Gerontological Nursing, 32(11), 8-13.

Gijsberts, M.-J. H. E., van der Steen, J. T., Muller, M. T., Hertogh, C. M. P. M., \& Deliens, L. (2013). Spiritual end-of-life care in Dutch nursing homes: an ethnographic study. Journal of the American Medical Directors Association, 14(9), 679-684. http://dx.doi.org/10.1016/j.jamda.2013.04.001

Gough, D., Oliver, S., \& Thomas, J. (2012). An introduction to systematic reviews. (1st ed. Vol. 1). London: SAGE Publications Ltd.pp. 288.

Gough, D., Thomas, J., \& Oliver, S. (2012). Clarifying differences between review designs and methods. Systems Review, 1, 28. http://dx.doi.org/10.1186/2046-4...

Group, W. S. (2006). A cross-cultural study of spirituality, religion, and personal beliefs as components of quality of life. Social Science \& Medicine, 62(6), 1486-1497.

Haugan, G., Rannestad, T., Garasen, H., Hammervold, R., \& Espnes, G. A. (2012). The selftranscendence scale: an investigation of the factor structure among nursing home patients. Journal of Holistic Nursing, 2012 Sep.

Haugan, G., Rannestad, T., Hanssen, B., \& Espnes, G. A. (2012). Self-transcendence and nurse-patient interaction in cognitively intact nursing home patients. Journal of Clinical Nursing, 21(23/24), 3429-3441. doi: 10.1111/j.1365-2702.2012.04217.x

Hodge, D. R., \& Horvath, V. E. (2011). Spiritual Needs in Health Care Settings: A Qualitative Meta-Synthesis of Clients' Perspectives. Social Work, 56(4), 306-316.

Hodge, D. R., Horvath, V. E., Larkin, H., \& Curl, A. L. (2012). Older Adults' Spiritual Needs in Health Care Settings: A Qualitative Meta-Synthesis. Research on Aging, 34(2), 131-155. doi: $10.1177 / 0164027511411308$ 
Kim, S.-S., Reed, P. G., Hayward, R. D., Kang, Y., \& Koenig, H. G. (2011). Spirituality and psychological well-being: testing a theory of family interdependence among family caregivers and their elders. Research in Nursing \& Health, 34(2), 103-115. doi: $10.1002 /$ nur.20425

Koenig, H. G. (2008). Concerns about measuring "spirituality" in research. Journal of Nervous and Mental Disease, 196(5), 349-355. doi: 10.1097/NMD.0b013e31816ff796

Liberati, A., Altman, D. G., Tetzlaff, J., Mulrow, C., Gøtzsche, P. C., Ioannidis, J. P. A., \& Moher, D. (2009). The PRISMA statement for reporting systematic reviews and metaanalyses of studies that evaluate healthcare interventions: explanation and elaboration (Vol. 339). http://dx.doi.org/10.1016/j.jcli...

MacKinlay. (2009). Using spiritual reminiscence with a small group of Latvian residents with dementia in a nursing home: A multifaith and multicultural perspective. Journal of Religion, Spirituality \& Aging, 21(4), 318-329.

MacKinlay, \& Trevitt, C. (2010). Living in aged care: Using spiritual reminiscence to enhance meaning in life for those with dementia. International Journal of Mental Health Nursing, 19(6), 394-401. doi: 10.1111/j.1447-0349.2010.00684.x

Malterud, K. (2001). Qualitative research: standards, challenges, and guidelines. The Lancet, 358(9280), 483-488. doi: 10.1016/S0140-6736(01)05627-6

Moher, D., Liberati, A., Tetzlaff, J., \& Altman, D. G. (2009). Preferred reporting items for systematic reviews and meta-analyses: the PRISMA statement (Vol. 339).

Narayanasamy, A. (2004). Spiritual care. The puzzle of spirituality for nursing: a guide to practical assessment. British Journal of Nursing (BJN), 13(19), 1140-1144.

Newlin, K., Knafl, K., \& Melkus, G. D. (2002). African-American spirituality: a concept analysis. Advances in Nursing Science, 25(2), 57-70. 
Noblit, G. W., \& Hare, R. D. (1988). Meta-ethnography: synthesizing qualitative studies (1st. edn ed.). Newbury Park, Calif.: Sage Publications. pp88.

O'Brien, M. E. (2011). Spirituality in nursing: standing on holy ground (4th ed.). Sudbury, Mass.: Jones \& Bartlett Learning. pp 432.

Pargament, K.I. (2007). Spiritually integrated psychotherapy: Understanding and addressing the sacred (1st ed.). New York, NY: Guilford Press; US. pp. 384.

Pargament, K.I., Magyar-Russell, G. M., \& Murray-Swank, N. A. (2005). The sacred and the search for significance: Religion as a unique process. Journal of Social Issues, 61(4), $665-687$.

Pargament, K. I., \& Mahoney, A. (2002). Spirituality: Discovering and conserving the sacred. Snyder, CR [Ed], 646-659.

Park, C. L. (2010). Making sense of the meaning literature: An integrative review of meaning making and its effects on adjustment to stressful life events. Psychological Bulletin, 136(2), 257-301. http://dx.doi.org/10.1037/a00183...

Pesut, B. (2008). Spirituality and spiritual care in nursing fundamentals textbooks. Journal of Nursing Education, 47(4), 167-173. http://dx.doi.org/10.3928/01484834-20080401-05

Pike, J. (2011). Spirituality in nursing: a systematic review of the literature from 2006-10. British Journal of Nursing, 20(12), 743-749.

Reed, P. G. (2014). Theory of Self- Transcendence. In: Middle range Theory for nursing. (Third Edition ed.). New York: Springer Publishing Company.

Rokstad, A. M. M., Røsvik, J., Kirkevold, Ø., Selbaek, G., Saltyte Benth, J., \& Engedal, K. (2013). The Effect of Person-Centred Dementia Care to Prevent Agitation and Other Neuropsychiatric Symptoms and Enhance Quality of Life in Nursing Home Patients: A 10-Month Randomized Controlled Trial. Dementia \& Geriatric Cognitive Disorders, 36(5/6), 340-353. doi: 10.1159/000354366 
Ross, L. (2006). Spiritual care in nursing: an overview of the research to date. Journal of Clinical Nursing, 15(7), 852-862. http://dx.doi.org/10.1111/j.13652702.2006.01617.x

Rykkje, L., Eriksson, K., \& Råholm, M.-B. (2011). A qualitative metasynthesis of spirituality from a caring science perspective. International Journal for Human Caring, 15(4), 4053.

Saini, M., \& Shalonsky, A. (Ed.). (2012). Systematic synthesis of qualitative research. $\left(1^{\text {st }}\right.$ ed.). Oxford: Oxford University Press Inc. pp.208.

Sandelowski, M. (2006). "Meta-Jeopardy": The crisis of representation in qualitative metasynthesis. Nursing Outlook, 54(1), 10-16.

Sandelowski, M. (2008). Reading, writing and systematic review. J Advanced Nursing, 64(1), 104-110.

Sawatzky, R., \& Pesut, B. (2005). Attributes of spiritual care in nursing practice. Journal of Holistic Nursing, 23(1), 19-33.

Schnell, T. (2011). Individual differences in meaning-making: Considering the variety of sources of meaning, their density and diversity. Personality and Individual Differences, 51(5), 667-673.

Sessanna, L., Finnell, D., \& Jezewski, M. A. (2007). Spirituality in nursing and health-related literature: a concept analysis. Journal of Holistic Nursing, 25(4), 252-262.

Smith, M., Hall, G., Gerdner, L., \& Buckwalter, K. (2006). Application of the progressively lowered stress threshold model across the continuum of care. Nursing Clinics of North America, 41(1), 57-81.

Streubert, H. J., \& Carpenter, D. R. (2011). Qualitative research in nursing : advancing the humanistic imperative (5th ed.). Philadelphia: Lippincott Williams \& Wilkins.pp. 470. 
Sullivan, S. C., \& Beard, R. L. (2014). Faith and forgetfulness: The role of spiritual identity in preservation of self with Alzheimer's. Journal of Religion, Spirituality \& Aging, 26(1), $65-91$.

Tanyi, R. A. (2002). Towards clarification of the meaning of spirituality. Journal of Advanced Nursing, 39(5), 500-509. http://dx.doi.org/10.1046/j.1365-2648.2002.02315.x

Teixeira, M. E. (2008). Self-transcendence: a concept analysis for nursing praxis. Holistic Nursing Practice, 22(1), 25-31.

Tranvåg, O., Petersen, K. A., \& Nåden, D. (2013). Dignity-preserving dementia care: A metasynthesis. Nursing Ethics, 20(8), 861-880. doi: 10.1177/0969733013485110

van de Geer, J., \& Leget, C. (2012). How spirituality is integrated system-wide in the Netherlands Palliative Care National Programme. Progress in Palliative Care, 20(2), 98-105.

Welsh, D., Moore, S. L., \& Getzlaf, B. A. (2012). Meaning in Life: The Perspective of LongTerm Care Residents. Research in Gerontological Nursing, 5(3), 185-194. doi: $10.3928 / 19404921-20120605-05$

Whittemore, R., \& Knafl, K. (2005). The integrative review: updated methodology. Journal of Advanced Nursing, 52(5), 546-553. http://dx.doi.org/10.1111/j.13652648.2005.03621.x

WHO. (2012). Dementia: a public health priority. Geneva: World Health Organization. 
Table 1. Noblit and Hare's (1988) phases of conducting a meta-synthesis.

\begin{tabular}{l|l} 
Phase 1 & Getting started. Identifying a topic of intellectual interest and the background \\
of the research themes that the qualitative research informs. Defining the aim.
\end{tabular}

\begin{tabular}{|c|c|}
\hline Phase 2 & $\begin{array}{l}\text { Deciding what is relevant to the initial interest. Including relevant studies, } \\
\text { describing the search strategy and criteria for inclusion and exclusion. }\end{array}$ \\
\hline Phase 3 & $\begin{array}{l}\text { Reading studies. Repeating reading of the studies noting their interpretative } \\
\text { metaphors. }\end{array}$ \\
\hline Phase 4 & $\begin{array}{l}\text { Determining the relationships between the studies. Reading the findings of } \\
\text { the primary studies and extracting metaphors, concepts and themes and their } \\
\text { potential relationships in the primary studies (first-level analysis), which ends } \\
\text { in an assumption of their relationship being reciprocal (findings across studies } \\
\text { are comparable), reputational (findings stand in opposition to each other) or } \\
\text { as representing a line of arguments. (Second level analysis) }\end{array}$ \\
\hline Phase 5 & $\begin{array}{l}\text { Translating the studies into each other (first-level synthesis). Comparing } \\
\text { metaphors and their interactions within single studies and across studies and } \\
\text { at the same time protecting uniqueness and holism. }\end{array}$ \\
\hline Phase 6 & $\begin{array}{l}\text { Synthesizing translations (second-level synthesis). Creating a new whole from } \\
\text { the sum of the parts. }\end{array}$ \\
\hline Phase 7 & $\begin{array}{l}\text { Expressing the synthesis. Finding the appropriate form for the synthesis to be } \\
\text { effectively communicated to the audience. }\end{array}$ \\
\hline
\end{tabular}


Table 2. Article search flowchart

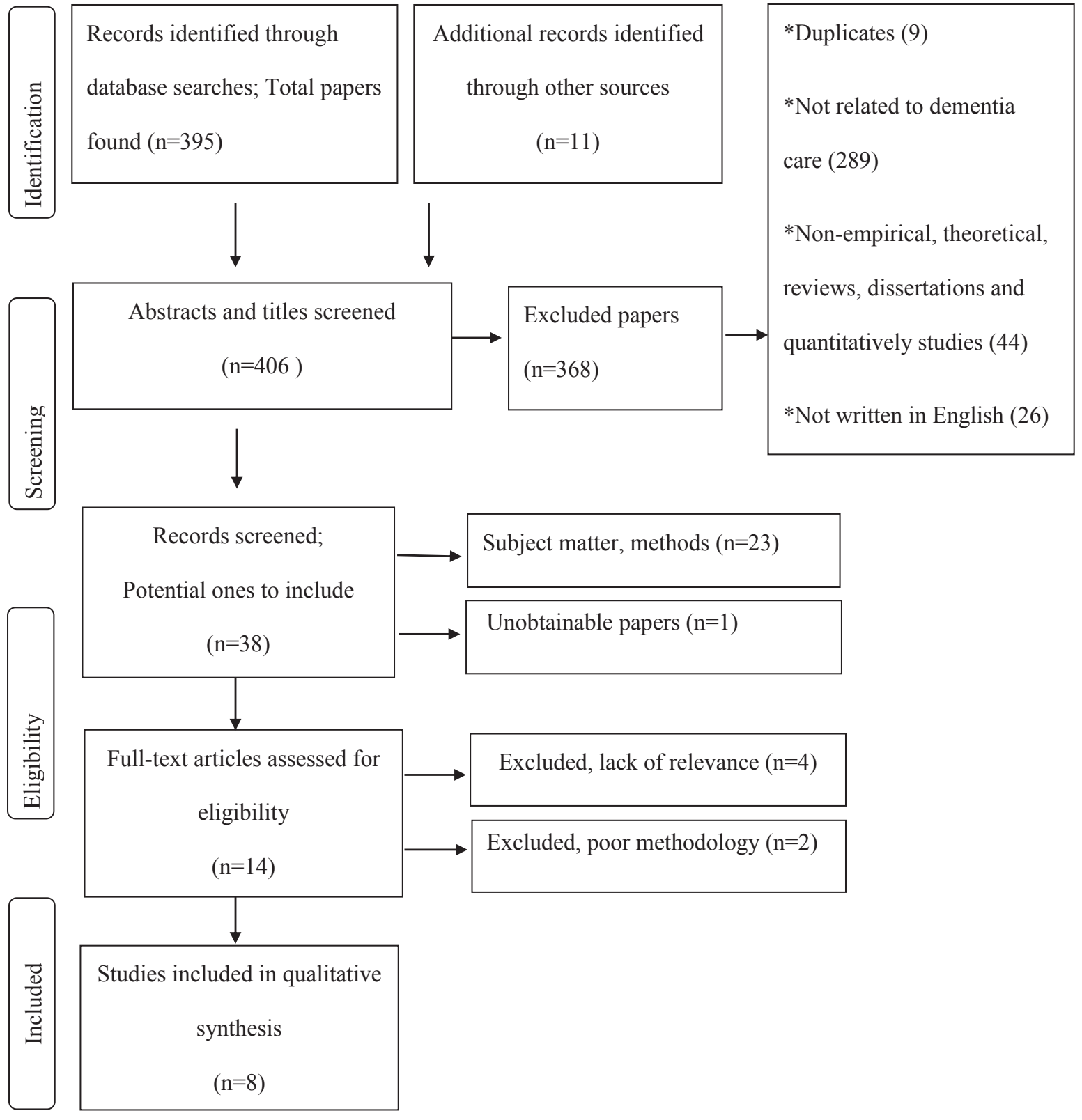

PRISMA 2009 Flow Diagram Moher D, Liberati A, Tetzlaff J, Altman DG, The PRISMA Group (2009). Preferred Reporting Items for Systematic Reviews and Meta- Analyses:The PRISMA Statement. PLoS Med 6(6): e1000097. doi:10.1371/journal.pmed1000097 
Table 3. Presentation of the studies included

\begin{tabular}{|c|c|c|c|c|c|}
\hline Author & Country & Aim & Methods & Participants & $\begin{array}{l}\text { Cultural } \\
\text { context, } \\
\text { setting }\end{array}$ \\
\hline $\begin{array}{l}\text { Bursell \& } \\
\text { Mayers, } \\
2010\end{array}$ & US & $\begin{array}{l}\text { To investigate how } \\
\text { different health } \\
\text { workers } \\
\text { understand } \\
\text { spirituality within } \\
\text { dementia, and how } \\
\text { they feel that such } \\
\text { needs should be } \\
\text { addressed and by } \\
\text { whom }\end{array}$ & $\begin{array}{l}\text { Phenomenological } \\
\text { approach } \\
\text { Convenience } \\
\text { sampling } \\
\text { Personal semi- } \\
\text { structured interviews } \\
\text { Content analysis }\end{array}$ & $\begin{array}{l}\mathrm{N}=11 \\
\text { Different health care } \\
\text { professionals } \\
\text { Nurses } \mathrm{n}=4 \\
\text { Doctors } \mathrm{n}=2 \\
\text { Occupational } \\
\text { therapists } \mathrm{n}=2 \\
\text { Psycho-therapists } \\
\mathrm{n}=2 \\
\text { Speech and } \\
\text { language therapists } \\
\mathrm{n}=1\end{array}$ & $\begin{array}{l}\text { Dementia } \\
\text { care service }\end{array}$ \\
\hline $\begin{array}{l}\text { Carr, Hicks- } \\
\text { Moore \& } \\
\text { Montgomer, } \\
2011\end{array}$ & Canada & $\begin{array}{l}\text { To explore how } \\
\text { spiritual care can } \\
\text { offer opportunities } \\
\text { for persons with } \\
\text { dementia and their } \\
\text { families to find and } \\
\text { sustain meaning, } \\
\text { purpose, and } \\
\text { personhood in life } \\
\text { and living }\end{array}$ & $\begin{array}{l}\text { Hermeneutic- } \\
\text { phenomenological } \\
\text { approach (van } \\
\text { Maanen) } \\
\text { Purposive sampling } \\
30 \text { open-ended } \\
\text { interviews } \\
25 \text { hours of } \\
\text { observation in the } \\
\text { field. } \\
\text { Thematic analysis }\end{array}$ & $\begin{array}{l}\mathrm{N}=29 \\
\text { Patients with } \\
\text { dementia } \mathrm{n}=8 \\
\text { Family members } \\
\mathrm{n}=5 \\
\text { Health care workers } \\
=11(\mathrm{RNs}=5, \mathrm{LPNs} \\
\text { and recreational } \\
\text { therapists }=6) \\
\text { Hospital chaplains= } \\
5\end{array}$ & $\begin{array}{l}\text { Long term } \\
\text { care } \\
\text { Dementia } \\
\text { care unit }\end{array}$ \\
\hline $\begin{array}{l}\text { Beuscher \& } \\
\text { Grando, } \\
2009\end{array}$ & US & $\begin{array}{l}\text { To investigate how } \\
\text { people with early } \\
\text { stages of } \\
\text { Alzheimer's } \\
\text { disease (AD) i) use } \\
\text { their spirituality to } \\
\text { cope with their } \\
\text { disease, ii) how } \\
\text { spiritual practices } \\
\text { support this } \\
\text { process, and iii) } \\
\text { how AD has } \\
\text { affected their }\end{array}$ & $\begin{array}{l}\text { Ethnographic } \\
\text { approach } \\
\text { Purposive sampling } \\
\text { Semi-structured } \\
\text { interviews in two } \\
\text { sessions }(\mathrm{N}=12) \\
\text { Semi-structured } \\
\text { interviews in three } \\
\text { sessions } \\
\text { (N=3) } \\
\text { Observation of the } \\
\text { participant's home, } \\
\text { field notes }\end{array}$ & $\begin{array}{l}\mathrm{N}=15 \\
\text { People with } \\
\text { Alzheimer's disease }\end{array}$ & $\begin{array}{l}\text { In the } \\
\text { patients' } \\
\text { homes }\end{array}$ \\
\hline
\end{tabular}




\begin{tabular}{|c|c|c|c|c|c|}
\hline & & $\begin{array}{l}\text { spirituality or } \\
\text { spiritual practices. }\end{array}$ & $\begin{array}{l}\text { analyzed by } \\
\text { Ethnographic version } \\
5.0 \text { computer } \\
\text { software }\end{array}$ & & \\
\hline $\begin{array}{l}\text { Dalby, } \\
\text { Sperlinger } \\
\& \\
\text { Boddington, } \\
2012\end{array}$ & UK & $\begin{array}{l}\text { 1) To understand } \\
\text { the experience of } \\
\text { spirituality in the } \\
\text { context of living } \\
\text { with dementia. } \\
\text { 2) To understand } \\
\text { the experience of } \\
\text { dementia in the } \\
\text { context of spiritual } \\
\text { beliefs. }\end{array}$ & $\begin{array}{l}\text { Phenomenological } \\
\text { approach } \\
\text { Exploratory study } \\
\text { Interpretive } \\
\text { Phenomenological } \\
\text { Analysis (IPA) } \\
\text { Semi-structured } \\
\text { interviews }\end{array}$ & $\begin{array}{l}\mathrm{N}=6 \\
\text { Patients with } \\
\text { dementia }\end{array}$ & $\begin{array}{l}\text { In the } \\
\text { patients' } \\
\text { own homes } \\
(\mathrm{n}=4) \\
\text { In assisted } \\
\text { living } \\
\text { facilities } \\
(\mathrm{N}=1) \\
\text { In care } \\
\text { homes } \\
(\mathrm{n}=1)\end{array}$ \\
\hline $\begin{array}{l}\text { Gijsberts, } \\
\text { van der } \\
\text { Steen, } \\
\text { Muller \& } \\
\text { Deliens, } \\
2013\end{array}$ & $\begin{array}{l}\text { Nether- } \\
\text { lands }\end{array}$ & $\begin{array}{l}\text { 1) If and how } \\
\text { spiritual needs are } \\
\text { assessed and } \\
\text { spiritual care is } \\
\text { provided to Dutch } \\
\text { nursing home } \\
\text { residents suffering } \\
\text { from dementia or } \\
\text { physical } \\
\text { disabilities. } \\
\text { 2) If and how } \\
\text { caregivers, } \\
\text { including } \\
\text { physicians, nurses, } \\
\text { and other staff, } \\
\text { communicate and } \\
\text { collaborate } \\
\text { regarding the topic } \\
\text { of addressing the } \\
\text { residents' spiritual } \\
\text { needs. }\end{array}$ & $\begin{array}{l}\text { Ethnographic } \\
\text { participatory study } \\
\text { Informal } \\
\text { conversations } \\
\text { Residents' care plans } \\
\text { Observations } \\
\text { Diaries } \\
\text { Field notes } \\
\text { Formal interviews } \\
\text { Thematic analysis }\end{array}$ & $\begin{array}{l}\mathrm{N}=13 \\
\text { Researchers } \mathrm{n}=2 \\
\text { Elderly care } \\
\text { physicians } \mathrm{n}=1 \\
\text { Social scientists } \mathrm{n}= \\
1 \\
\text { Nurses } \mathrm{n}=4 \\
\text { Physicians } \mathrm{n}=3 \\
\text { Spiritual counsellors } \\
\mathrm{n}=1 \\
\text { Residents } \mathrm{n}=2 \\
\text { Resident's proxies } \\
\mathrm{n}=1\end{array}$ & $\begin{array}{l}\text { Urban } \\
\text { Nursing } \\
\text { Home units } \\
\mathrm{n}=2 \\
\text { Psycho- } \\
\text { geriatric } \\
\text { units } \mathrm{n}=1 \\
\text { Somatic } \\
\text { units for } \\
\text { residents } \\
\text { with } \\
\text { physical } \\
\text { disabilities } \\
\mathrm{n}=1\end{array}$ \\
\hline
\end{tabular}




\begin{tabular}{|c|c|c|c|c|c|}
\hline $\begin{array}{l}\text { MacKinlay } \\
\& \text { Trevitt, } \\
2010\end{array}$ & Australia & $\begin{array}{l}\text { To evaluate the } \\
\text { effectiveness of } \\
\text { spiritual } \\
\text { reminiscence as a } \\
\text { method for } \\
\text { assisting older } \\
\text { people with } \\
\text { dementia to find } \\
\text { meaning in their } \\
\text { life-situations. }\end{array}$ & $\begin{array}{l}\text { Phenomenological } \\
\text { perspective } \\
\text { Grounded theory } \\
\text { NVIVO } \\
\text { Qualitative analysis } \\
\text { of interviews } \\
\text { Group sessions over } \\
\text { a period of } 6 \text { or } 24 \\
\text { weeks with spiritual } \\
\text { reminiscence } \\
\text { Observer journals }\end{array}$ & $\begin{array}{l}\mathrm{N}=113 \\
\text { People with } \\
\text { dementia } \\
\text { Groups with } 3-6 \\
\text { participants in each } \\
\mathrm{n}=24\end{array}$ & $\begin{array}{l}\text { Aged care } \\
\text { facilities }\end{array}$ \\
\hline $\begin{array}{c}\text { Sullivan \& } \\
\text { Beard, } 2014\end{array}$ & US & $\begin{array}{l}\text { To understand the } \\
\text { role of } \\
\text { religion/spirituality } \\
\text { in the illness } \\
\text { narratives of } \\
\text { seniors with } \\
\text { memory loss, } \\
\text { documenting the } \\
\text { role of one } \\
\text { potential positive } \\
\text { resource, religious } \\
\text { identity or } \\
\text { spirituality central } \\
\text { to experiences of } \\
\text { self and social } \\
\text { identity. }\end{array}$ & $\begin{array}{l}\text { Inductive } \\
\text { In-person individual } \\
\text { and group interviews } \\
\text { Convenience and } \\
\text { snowball sampling } \\
\text { Interview guide } \\
\text { Analysis using "a } \\
\text { constant comparative } \\
\text { method and coding } \\
\text { paradigm" in line } \\
\text { with grounded theory } \\
\text { and thematic content } \\
\text { analysis. }\end{array}$ & $\begin{array}{l}\mathrm{N}=75 \\
\text { People with } \\
\text { Alzheimer's disease } \\
(\mathrm{AD} / \mathrm{MCI})(\mathrm{n}=31) \\
\text { and family members } \\
(\mathrm{n}=44) .\end{array}$ & Home care \\
\hline $\begin{array}{l}\text { Welsh, } \\
\text { Moore \& } \\
\text { Getzlaf, } \\
2012\end{array}$ & $\begin{array}{l}\text { Newfoun } \\
\text { dland, } \\
\text { Canada }\end{array}$ & $\begin{array}{l}\text { To explore } \\
\text { meaning in life for } \\
\text { long-term care } \\
\text { residents. }\end{array}$ & $\begin{array}{l}\text { Hermeneutic- } \\
\text { phenomenological } \\
\text { Purposive sampling } \\
\text { In-depth, semi- } \\
\text { structured interviews } \\
\text { Analyzed by van } \\
\text { Manen i) lived time } \\
\text { ii) lived space, ii) } \\
\text { lived body iv) lived } \\
\text { relation }\end{array}$ & $\begin{array}{l}\mathrm{N}=11 \\
\text { Residents from a } \\
\text { rural area in Canada }\end{array}$ & $\begin{array}{l}\text { Long-term } \\
\text { care }\end{array}$ \\
\hline
\end{tabular}


Table 4. First level synthesis based on the second level analysis

\begin{tabular}{|c|c|}
\hline Second-level analysis & First-level synthesis \\
\hline $\begin{array}{l}\text { Spiritual care encompasses strengthening peoples' needs for } \\
\text { religious faith expression, a relationship with God and a religious } \\
\text { identity and facilitates religious practices such as prayers, } \\
\text { readings and church attendance. }\end{array}$ & $\begin{array}{l}\text { Performing religious rituals } \\
\text { with patients to provide a } \\
\text { sense of comfort. }\end{array}$ \\
\hline $\begin{array}{l}\text { Spiritual care encompasses the promotion of the person's values } \\
\text { and hopes for the future. } \\
\text { Help patients to maintain their relationships with themselves and } \\
\text { others and to maintain a sense of connectedness. }\end{array}$ & $\begin{array}{l}\text { Coming to know the person } \\
\text { provides opportunities to } \\
\text { understand their meaning } \\
\text { and purpose }\end{array}$ \\
\hline $\begin{array}{l}\text { Strengthen the person's need for integrity and perseverance of } \\
\text { "self" that promote personhood and feelings of being valued. } \\
\text { Support and help people to find meaning in life. }\end{array}$ & \\
\hline $\begin{array}{l}\text { Spiritual care encompasses engaging the person in familiar } \\
\text { activities that give a sense of contribution and spiritual } \\
\text { reminiscence. }\end{array}$ & $\begin{array}{l}\text { Attending to basic needs } \\
\text { provides an opportunity to } \\
\text { appreciate others' } \\
\text { vulnerability and } \\
\text { humanness. }\end{array}$ \\
\hline
\end{tabular}


Table 5. Second-level synthesis of spiritual care in dementia care

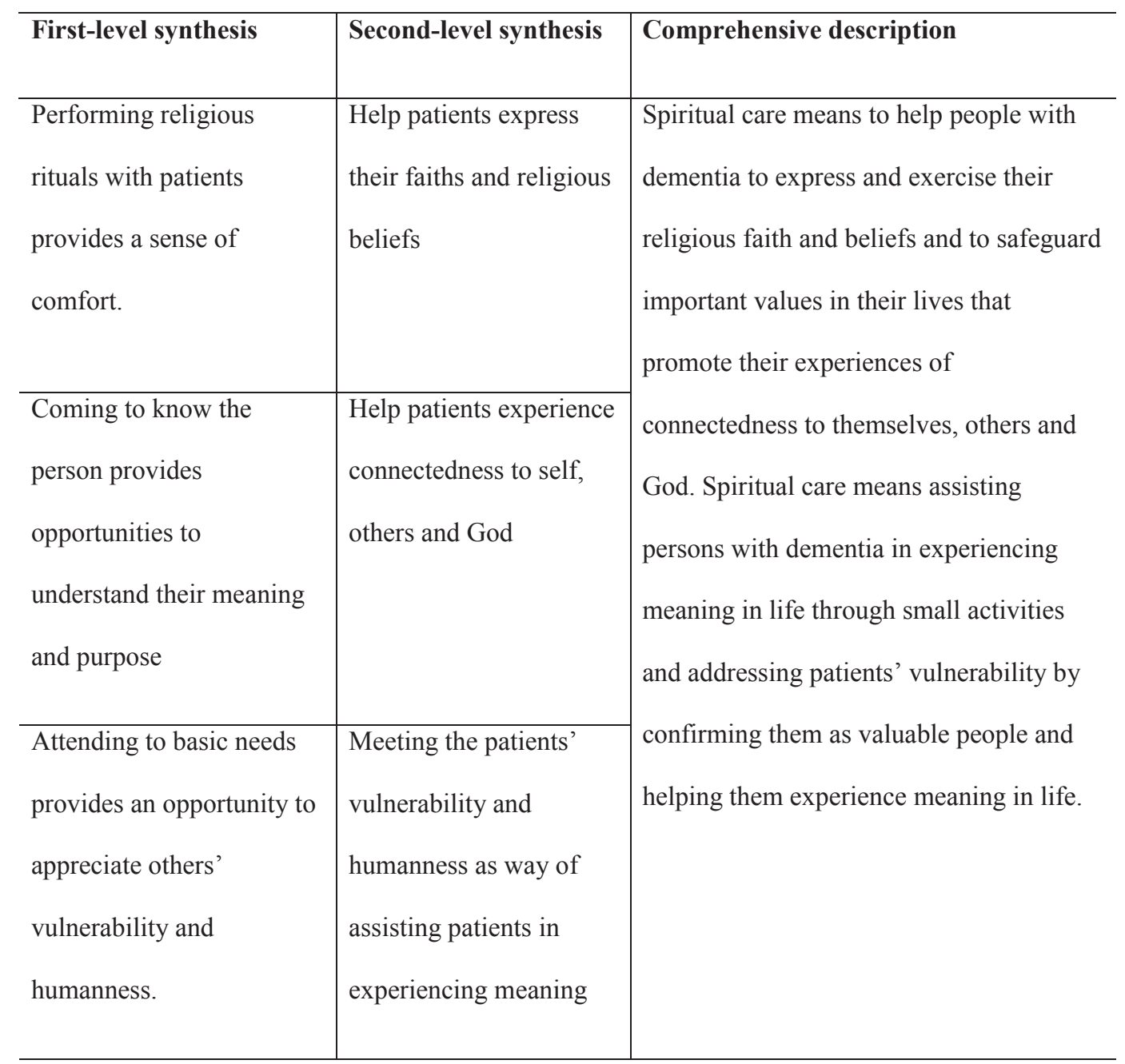

